\title{
電解酸化法を用いた活性炭の表面官能基の生成
}

\section{Formation of functional groups on an activated carbon material surface using electrochemical oxidation}

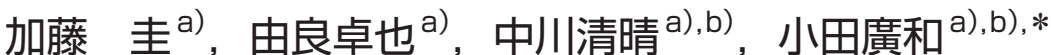

Kei Kato ${ }^{\text {a)}}$, Takuya Yura ${ }^{\text {a) }}$, Kiyoharu Nakagawa ${ }^{\text {a),b) }}$ and Hirokazu Oda ${ }^{\text {a),b),* }}$

We discuss the control of functional groups on an activated carbon surface using electrochemical oxidation. As a result, this method could introduce surface functional groups into activated carbon without a major change of the pore structure. Carboxyl groups were introduced under strong oxidation conditions and lactone was formed under mild oxidation condition. This electrochemical oxidation method could control the functional groups generated on an activated carbon surface.

KEYWORDS : Electrochemical oxidation, Functional group containing oxygen, Activated carbon

\section{1. 緒 言}

近年，エネルギーや環境問題の観点から蓄電デバイスとして リチウムイオン二次電池，キャパシタなどに関する研究が活発 に行われている。これらの蓄電デバイスの電極材には主に炭素 材料が用いられている1)。しかし，水系電解液を使用したキャ パシ夕などの電極材として用いる場合，炭素材料は疎水性が強 いため，炭素材料同士が凝集し溶媒やその他の材料と均一に分 散しづらいという課題がある。この課題を解決するためには, 炭素材料の表面にカルボキシル基などの親水性の官能基を導入 し，炭素材料の親水性・分散性を向上させる手法が一般に用い られている。炭素材料表面に表面官能基を導入する手法は，現 在まで多数提案 ${ }^{2-4)}$ されて㧍り, 分子状酸素などの酸化剂を含 む雲囲気下での気相酸化法, 硫酸や過酸化水素などを用いた液 相酸化法がある。また，印加電圧や時間などの酸化条件を任意 に変化させることで酸化の程度を比較的制御しやすい電解酸化 法5)-7) どが検討されている。高配向性熱分解黒鉛(HOPG)を 用いた電解酸化について，衣本らによる詳細な検討がなされて 抢り，印加電圧 $1.0 \mathrm{~V}$ までの電解酸化において，結晶性の高い 黒鉛では $0.2 \sim 1.0 \mathrm{~V}$ の間でアルコールやカルボニル基が表面に 導入され，1.0 Vでは表面の酸化が加速されることが報告され ている ${ }^{8)-10)}$ 。炭素表面に導入される官能基にはさまざまな種類 が存在し，機能性炭素材料を設計するためには，炭素の表面状 態を把握することが重要である。

本報では，活性炭表面への官能基導入を制御して行うことを 目的として，酸化条件を任意に変化させることのできる電解酸
化法を用いて活性炭表面の電解酸化を行い，表面官能基の導入 を検討した。また，表面電解酸化を施した活性炭表面に生成し た官能基の定性㧍よび定量分析を行うことで，活性炭の表面 官能基の生成と酸化条件（印加電圧）との関連について検討を 行った。

\section{2. 実験方法}

\section{1 活性炭の電解酸化}

使用した活性炭には，一般的にキャパシタの電極材などに 多く用いられている梛子殼活性炭（三菱化学製，DIASORB G4-8，以下ACs-orig.）を粉砕し，100 meshのふるいにかけて 一晚真空乾燥したものを用いた。電解酸化（陽極酸化）装置 として，Fig. 1に示す通液型装置（液貯め容積 $1.0 \mathrm{~L}$ ）を使用し

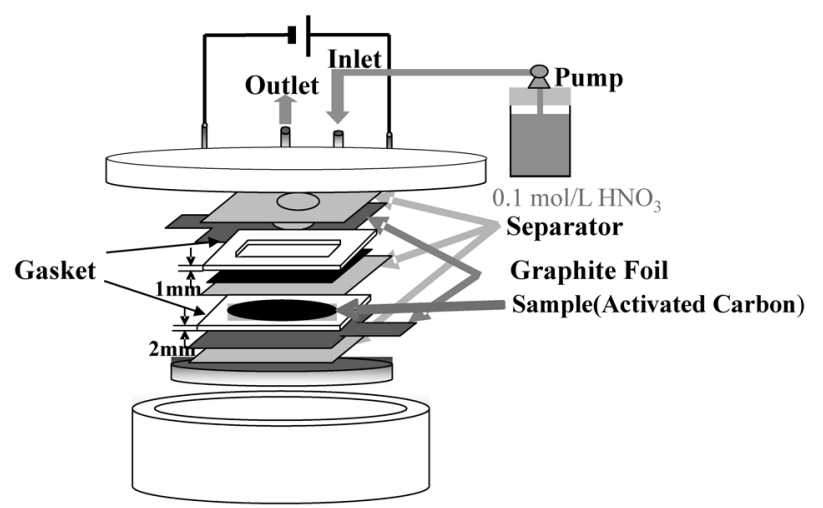

Fig. 1 Schematic of the experimental setup chamber used to electro-oxidation of ACs.

* Corresponding Author, E-mail: oda@kansai-u.ac.jp

(平成27年6月29日受理，平成28年3月9日採択)

a) 関西大学環境都市工学部工ネルギー・環境工学科：テ564-8680 大阪府吹田市山手町3-3-35

Department of Chemical Engineering, Kansai University: 3-3-35 Yamate-cho, Suita, Osaka 564-8680, Japan

b) 関西大学ハイテクリサーチコア $(H R C)$ : =564-8680 大阪府吹田市山手町3-3-35

High Technology Research Core (HRC), Kansai University: 3-3-35 Yamate-cho, Suita, Osaka 564-8680, Japan http://dx.doi.org/10.7209/tanso.2016.96 
た。集電体に溶液を流通させるため均等に約 $0.5 \mathrm{~mm}$ の穴を空 けたグラファイトフォイル（東洋炭素製）を使用し，セパレー タにはろ紙（ADVANTEC製，No. 5C)，シリコンのガスケット 用いて ACs-orig. $1.0 \mathrm{~g}$ をセ゚レータとグラファイトフォイルの 間に挟んで作製した（Fig. 1参照）。電解液に $0.1 \mathrm{M} \mathrm{HNO}_{3}$ を用 い, 装置内に通液 $(1.0 \mathrm{ml} / \mathrm{min})$ させながら室温で, それぞれ印 加電圧を $0 \sim 3.0 \mathrm{~V}$ の間で変化させて 1 時間電解酸化反応を行っ た。その後, 純水で $\mathrm{pH}=7$ になるまで洗浄した後, 一晚乾燥し て試料(ACs-O) を得た。印加電圧 $3.0 \mathrm{~V}$ で電解酸化した試料を ACs-O $3.0 \mathrm{~V}$ と命名し, 以下ACs-orig., ACs-O 0.5 V, ACs-O $1.0 \mathrm{~V}$, ACs-O 1.5 V, ACs-O 2.0 V, ACs-O 2.5 V, ACs-O 3.0 V と表記した。

\section{2 細孔構造評価}

ACs-orig. およびACs-Oの細孔構造および物性評価は, 比表 面積測定装置（日本ベル製，BELSORP28）を用いて $77 \mathrm{~K}$ 窒素 吸着等温線を測定した。B.E.T.法より比表面積, DR (Dubinin Radushkevich)法よりミクロ孔容積を, DH (Dollimore Heal) 法よ りメソ孔容積をそれぞれ求めた。

\section{3 表面官能基の分析}

$\mathrm{X}$ 線光電子分光法 (XPS：線源 $\mathrm{Mg} K \alpha$ 平均エネルギー $1253.56 \mathrm{eV}, \mathrm{JEOL}$ 製，JPS-9000MX）を用い，ACs-O表面に生 成した表面官能基の定性分析および存在比率を求めた。

表面官能基の定性分析は，拡散反射FT-IR法によって行った。 ACs-O と KBr粉末を混練してFT-IR (JMS-7000) (Fourier Transform Infrared Spectroscopy, フーリエ変換赤外分光光度計, 日本 電子(株) 製) を用い，4000 500 $\mathrm{cm}^{-1}$ の波数範囲で測定した。

ACs-O の表面官能基の定量分析は, 酸塩基中和滴定法 $\left(\right.$ Boehm 法 $^{11)}$ ) により表面に存在するカルボキシル基，ラクト ン基，フェノール性水酸基の量をそれぞれ求めた。

ここで酸塩基中和滴定法とは，活性炭に各種のアルカリを加 えて反応させ，反応後のアルカリの濃度を酸で逆滴定すること で活性炭表面に存在する酸性官能基量を定量する方法である。 酸性度の違いから, 水酸化ナトリウムは, カルボキシル基, ラ クトン基, フェノール性水酸基と, 炭酸ナトリウムはカルボキ シル基，ラクトン基と, 炭酸水素ナトリウムはカルボキシル基 とそれぞれ反応することを利用して, 各酸性官能基量を分別定 量できる。

はじめにACs-orig. およびACs-Oを $383 \mathrm{~K}, 2$ 時間，真空乾 燥した。乾燥後, 炭酸水素ナトリウム $(0.1 \mathrm{~mol} / \mathrm{L})$, 炭酸ナト リウム $(0.05 \mathrm{~mol} / \mathrm{L})$, 水酸化ナトリウム $(0.1 \mathrm{~mol} / \mathrm{L})$ をそれぞれ $60 \mathrm{ml}$ に測定試料を $0.3 \mathrm{~g}$ 添加して室温で 48 時間撹拌した。な お，このとき空試験のためそれぞれの溶液を $60 \mathrm{ml}$ 準備した。 それぞれのろ液を $15 \mathrm{ml} \times 3$ 回ホールピペットで採取し, 塩酸 $(0.1 \mathrm{~mol} / \mathrm{L})$ で中和滴定をした。中和滴定の操作は, 電位差自動 滴定装置（京都電子工業(株)製，AT-510）を用いて行った。

また，自動昇温脱離スペクトル装置（日本ベル製，TPD1-AT-w) を用い, 昇温脱離(Temperature Programmed Desorption；TPD)法により各温度域で発生した気体を分別定量した。 ACs-O の $50 \mathrm{mg}$ を石英セル中に充填し, $\mathrm{He}$ ガスを $50 \mathrm{ml} / \mathrm{min}$
供給させ， $5 \mathrm{~K} / \mathrm{min} て ゙$ 昇温して，1173 Kまでの脱離ガスを検出 した。脱離ガスの分析には，四重極型質量分析計(Q-Mass)を 用いた。

\section{3. 結果と考察}

\section{1 電解酸化反応が細孔構造に及ぼす影響}

Table 1にACs-orig. の電解酸化反応前後の比表面積, ミクロ 孔容積, メソ孔容積を示す。印加電圧 $0.5 \sim 3.0 \mathrm{~V}$ の反応条件下 での電解酸化反応前後で, ミクロ孔容積およびメソ孔容積に大 きな変化は見られなかった。一般的に活性炭やカーボンブラッ クなどの多孔性炭素材料は, 分子状酸素などを用いた気相酸化 反応によって表面官能基を導入すると細孔構造の物理的な変化 は少ないが，カルボキシル基などの比較的大きな表面官能基が 細孔入り口付近に生成することなどにより，窒素の吸着を妨 げ，比表面積が小さく評価されることが知られている ${ }^{12)}$ 。

本酸化条件下での電解酸化処理はACs-orig.の比表面積に大 きな変化を与えずに酸化することが可能であることがわかっ た。

\subsection{XPSによる表面官能基の分析}

Table 2にACs-orig.の電解酸化反応後のXPSにより測定し た結果を示す。XPSのスペクトルから C1s $(284.7 \mathrm{eV} ， \mathrm{C}-\mathrm{C}$ 結 合）および $\mathrm{O} 1 \mathrm{~s}$ (532 eV 付近) の強度を求め, それぞれの比 $(\mathrm{O} 1 \mathrm{~s} / \mathrm{C} 1 \mathrm{~s})$ から表面官能基の存在比率の変化を検討した。印加 電圧が増加するのに伴い, O1s/C1s 比が増加し，表面に酸素種 が増加したことが推測される。また，印加電圧が増加するの に伴い，C1sのピークの高結合エネルギー側に官能基の生成に 起因するピークが複数出現した。 $\mathrm{C} 1 \mathrm{~s}$ の narrow scanにより得ら

Table 1 BET surface areas and pore structure characteristics of ACs-orig. and ACs-O samples.

\begin{tabular}{lccc}
\hline Sample & $S_{\text {BET }}\left[\mathrm{m}^{2} / \mathrm{g}\right]$ & $V_{\text {micro }}[\mathrm{ml} / \mathrm{g}]$ & $V_{\text {meso }}[\mathrm{ml} / \mathrm{g}]$ \\
\hline ACs-orig. & 1080 & 0.36 & 0.12 \\
ACs-O 0.5 V & 1080 & 0.42 & 0.11 \\
ACs-O 1.0 V & 1100 & 0.52 & 0.13 \\
ACs-O 1.5 V & 1080 & 0.48 & 0.11 \\
ACs-O 2.0 V & 1130 & 0.44 & 0.13 \\
ACs-O 2.5 V & 1030 & 0.40 & 0.11 \\
ACs-O 3.0 V & 1130 & 0.49 & 0.14 \\
\hline
\end{tabular}

Table 2 Atomic content of various carbon bonding and $\mathrm{O} 1 \mathrm{~s} / \mathrm{C} 1 \mathrm{~s}$ ratio in ACs-orig. and ACs-O samples taken from deconvoluted $\mathrm{C} 1 \mathrm{~s}$ spectra.

\begin{tabular}{lcccc}
\hline \multirow{2}{*}{ Sample } & \multicolumn{3}{c}{$\mathrm{C} 1 \mathrm{~s}[\%]$} \\
\cline { 2 - 4 } & $\begin{array}{c}\mathrm{C}-\mathrm{O} \\
(285.2 \mathrm{eV})\end{array}$ & $\begin{array}{c}\mathrm{C}=\mathrm{O} \\
(286.6 \mathrm{eV})\end{array}$ & $\begin{array}{c}\mathrm{O}-\mathrm{C}=\mathrm{O} \\
(287.9 \mathrm{eV})\end{array}$ & \\
\hline ACs-orig. & 60.3 & 14.7 & 25.0 & 0.45 \\
ACs-O 0.5 V & 58.2 & 14.2 & 27.6 & 0.47 \\
ACs-O 1.0 V & 64.4 & 16.0 & 19.6 & 0.46 \\
ACs-O 1.5 V & 55.9 & 14.3 & 29.8 & 0.55 \\
ACs-O 2.0 V & 61.1 & 20.8 & 18.0 & 0.67 \\
ACs-O 2.5 V & 53.9 & 13.6 & 32.5 & 0.70 \\
ACs-O 3.0 V & 57.3 & 10.2 & 32.5 & 0.71 \\
\hline
\end{tabular}


れたフェノール性水酸基などに起因する $285.2 \mathrm{eV}$ 付近のC-O 結 合 ${ }^{13)}$ のピークはACs-orig. およびACs-Oすべてに認められた。 ラクトン基などに起因する $286.6 \mathrm{eV}$ 付近の $\mathrm{C}=\mathrm{O}$ 結合 ${ }^{13)}$ のピー クはACs-O $2.0 \mathrm{~V}$ で増加し, カルボキシル基などに起因する $287.9 \mathrm{eV}$ 付近の $\mathrm{O}-\mathrm{C}=\mathrm{O}$ 結合 ${ }^{13)}$ のピークは $\mathrm{ACs}-\mathrm{O} 2.5 \mathrm{~V}$ で最大と なった。

Table 2の反応前後の $\mathrm{O} 1 \mathrm{~s} / \mathrm{C} 1 \mathrm{~s}$ の值と $\mathrm{C} 1 \mathrm{~s}$ の narrow scanにより ピーク分離から求めた $\mathrm{C}-\mathrm{O}, \mathrm{C}=\mathrm{O}, \mathrm{O}-\mathrm{C}=\mathrm{O}$ の活性炭表面におけ る存在比率は, $\mathrm{C}-\mathrm{O}$ は印加電圧の $0 \sim 3.0 \mathrm{~V}$ の範囲では増減はあ るが $60 \%$ 前後で推移し, C=O はACs-O $2.0 \mathrm{~V} て ゙$ 最大值となり, $\mathrm{O}-\mathrm{C}=\mathrm{O}$ の $1.0 \sim 2.0 \mathrm{~V}$ では大きく増減し ACs-O 2.0 Vで最も減少 したが，ACs-O 2.5 V 以上で再び増加し，ACs-O 2.5 および $3.0 \mathrm{~V}$ ではO-C=Oが約 $33 \%$ まで増加した。この酸化過程で， $\mathrm{C}=\mathrm{O}$, $\mathrm{O}-\mathrm{C}=\mathrm{O}$ の存在比率が大きく変化した。はじめは印加電圧の上 昇とともにラクトン基，カルボキシル基およびケトン基が生成 した。次に印加電圧の上昇に伴い，生成した官能基が分解，逐 次酸化されて $\mathrm{C}=\mathrm{O}, \mathrm{O}-\mathrm{C}=\mathrm{O}$ の存在比率が変化したものと考え られる。フェノール性水酸基などの $\mathrm{C}-\mathrm{O}$ 結合をもつ官能基は大 きな増減は見られなかった。 HOPGの電解酸化においても C-O と $\mathrm{C}=\mathrm{O}$ の間には平衡関係が存在し, 高い印加電圧では $\mathrm{C}=\mathrm{O}$ は $\mathrm{O}-\mathrm{C}=\mathrm{O}$ への酸化プロセスが提案されている ${ }^{10)}$ 。印加電圧が異 なるが，本実験においても印加電圧 $0 \sim 3.0 \mathrm{~V}$ の間で印加電圧上 昇に伴う各官能基の単調な増減が起こっていない理由として, 各官能基間に同様な関係が存在する可能性が考えられる。

\subsection{FT-IRによる表面官能基の定性分析}

Fig. 2にACs-orig. の電解酸化反応後の拡散反射法によって 測定した 800 から $2000 \mathrm{~cm}^{-1}$ までのIRスペクトルを示す。ACsorig. およびすべてのACs-Oにおいて，1000 1220 $\mathrm{cm}^{-1}$ 付近に $\mathrm{C}-\mathrm{O}$ の伸縮振動 ${ }^{14)}$, O-H 変角振動 ${ }^{14)}{ }^{15)}$ に対応する吸収が確認さ れ，フェノール性水酸基やカルボキシル基などの官能基が生成 していると考えられる。ACs-Oについては印加電圧の増加に伴 い, $1120 \sim 1200 \mathrm{~cm}^{-1}$ 付近にC-Oの伸縮振動のピーク強度が強 くなっていることがわかる。約 $1600 \sim 1800 \mathrm{~cm}^{-1}$ 付近の二つの ピークはラクトン基, カルボニル基, カルボキシル基の $\mathrm{C}=\mathrm{O}$ 伸縮振動 ${ }^{15)}$ に起因する吸収であり, 約 $1400 \mathrm{~cm}^{-1}$ 付近のピーク はフェノール性水酸基の $\mathrm{C}-\mathrm{O}$ 伸縮振動 ${ }^{16)}$ に起因する吸収と考 えられる。これらの結果からフェノール性水酸基はすべての ACs-orig. およびACs-Oで認められ, ACs-Oにおいては印加電 圧の増加に伴いカルボキシル基が増加していることが示唆され た。これらの傾向はXPSの結果とほぼ一致した。

\section{4 酸塩基中和滴定法による表面官能基の定量}

Fig. 3に酸塩基中和滴定法によって求めたACs-orig. の電解 酸化反応後の表面官能基量（フェノール性水酸基，ラクトン 基，カルボキシル基）とそれから求めた表面酸素量を示す。印 加電圧 $1.5 \mathrm{~V}$ 以上から表面官能基の生成による官能基量が増加

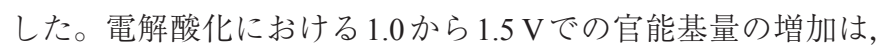
Table 2に示すXPSスペクトルから求めた $\mathrm{O} 1 \mathrm{~s} / \mathrm{C} 1 \mathrm{~s}$ の值の増加 傾向とよく一致している。各表面官能基の生成量は印加電圧

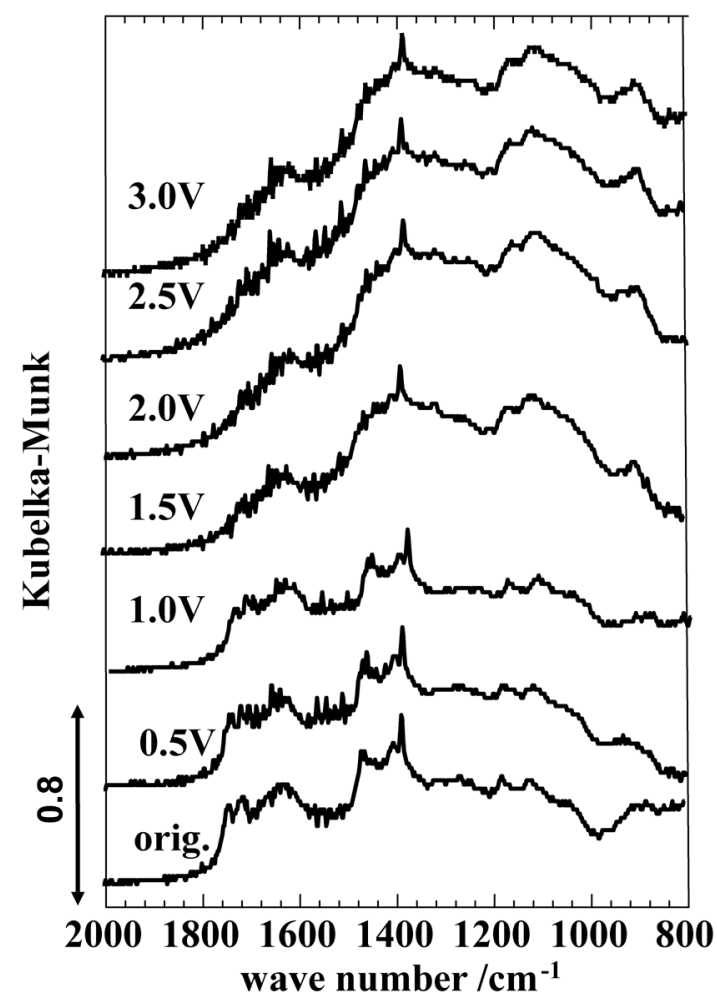

Fig. 2 Diffuse reflectance FT-IR spectra of ACs-orig. and ACs-O samples $\left(800 \sim 2000 \mathrm{~cm}^{-1}\right)$.

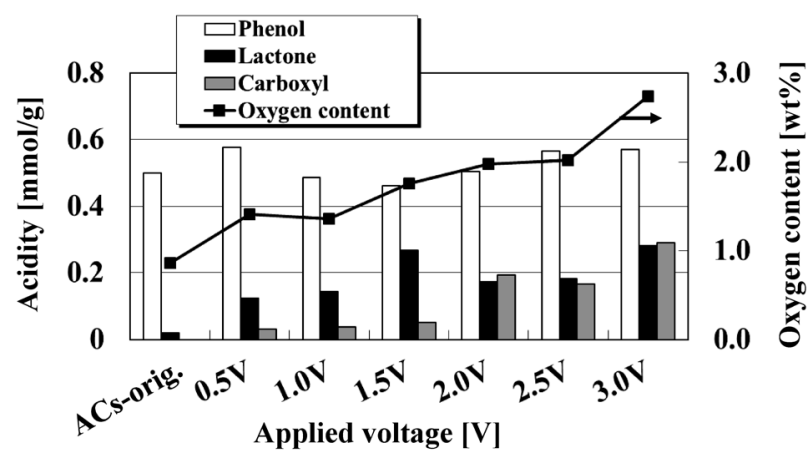

Fig. 3 Amounts of functional groups using the titration method.

$1.5 \mathrm{~V}$ の比較的穏やかな酸化条件下ではラクトンが，印加電圧 $2.0 \mathrm{~V}$ 以上の強い酸化条件ではカルボキシル基が増加した。こ のことから，穏やかな酸化条件下では主にラクトンが，強い酸 化条件下ではカルボキシル基が生成するものと考えられる。こ れは $\mathrm{O} 1 \mathrm{~s}$ スペクトルの解析結果と一致する。一方，印加電圧を 大きくしてもフェノール性水酸基の量は変化しなかった。

\subsection{TPDによる表面官能基の定量}

Fig. 4にACs-orig. の電解酸化反応後の昇温脱離(TPD)によっ て生成した $\mathrm{CO}, \mathrm{CO}_{2}$ の生成量と酸素含有量を示す。生成する $\mathrm{CO}$ はフェノール性水酸基, カルボニル基, $\mathrm{CO}_{2}$ はカルボキシ ル基，ラクトン基に由来すると考えられている ${ }^{17)}$ 。酸素含有 量は，印加電圧の変化とともに増加した。COの生成量は印加 電圧 $2.0 \mathrm{~V}$ 以上で増加した。 $\mathrm{CO}$ の生成量は $\mathrm{ACs}-\mathrm{O}$ 表面に生成 したカルボニル基などの生成量に比例するもの ${ }^{17)}$ と考えられ る。 $\mathrm{CO}_{2}$ の生成量は印加電圧 $2.5 \mathrm{~V}$ 以上から増加し, これに起 
因するカルボキシル基 ${ }^{17)}$ が生成したと考えられる。これまで のXPS，中和滴定の結果から印加電圧の増加に伴い, ACs-orig. に導入された含酸素官能基量は増加している。TPDによって測 定された $\mathrm{CO}, \mathrm{CO}_{2}$ の生成量はXPSの結果と同じような傾向が得 られた。なかでも強い酸化条件下で酸化した $\mathrm{ACs}-\mathrm{O} の \mathrm{CO}_{2}$ の生 成量の増加傾向はXPS および酸塩基中和滴定法の結果の傾向 とほぼ一致した。また, 昇温脱離反応時, $\mathrm{H}_{2} \mathrm{O}$ の生成も確認し ており，それはフェノール性水酸基とカルボキシル基の脱離反 応に起因する ${ }^{18)}$ と考えられることから，強い酸化条件下では カルボキシル基が生成したことが示唆される。

\section{6 酸塩基中和滴定法及び TPD 法の測定結果の比較}

Fig. 5に酸塩基中和滴定法 $\left(\mathrm{O}^{\mathrm{a}}\right)$ および昇温脱離法 $\left(\mathrm{O}^{\mathrm{b}}\right)$ により 得られた電解酸化によって導入された酸素含有量の関係を示 す。二つの手法ともに高い印加電圧で得られたACs-O中の酸 素含有量は増加し，その傾向はほぼ一致した。ここで，酸塩基 中和滴定法で求めた官能基量と昇温脱離法で得られた官能基量

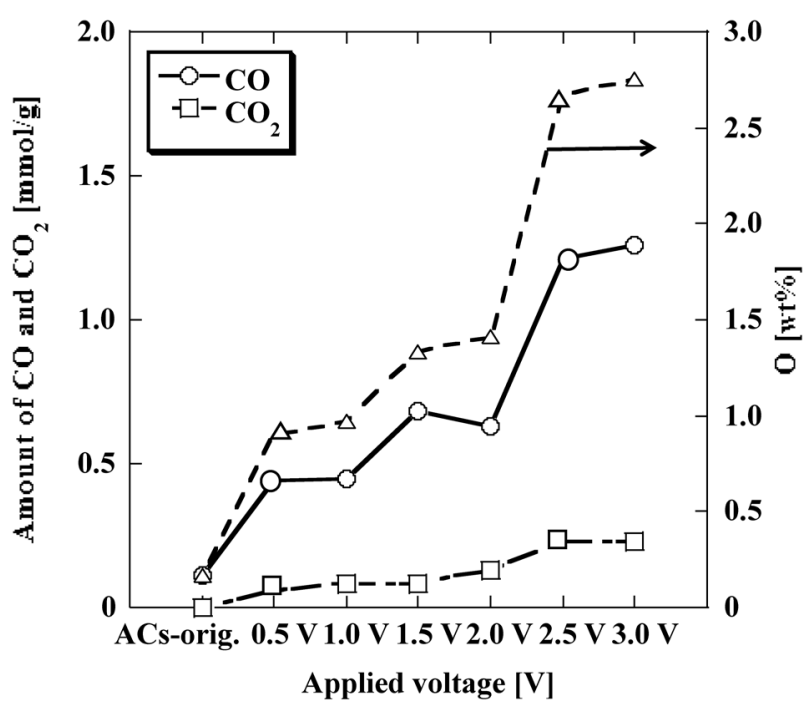

Fig. 4 Amount of $\mathrm{CO}$ and $\mathrm{CO}_{2}$ desorbed from ACs-orig. and ACs-O samples using TPD measurement.

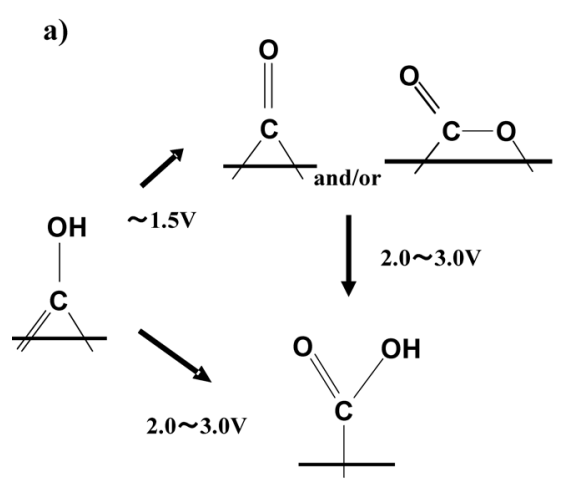

b)

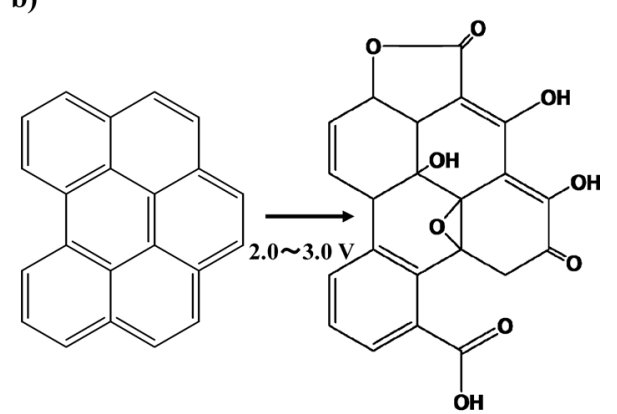

c)

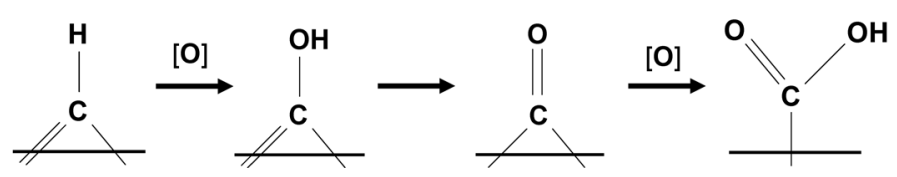

Fig. 6 Proposed mechanism of functional groups containing oxygen on activated carbon surface during the oxidation. a), b) proposed mechanism. c) Ref. 5: Z. R. Yue et al., Carbon 37 (1999) 1785-1796.
は，厳密には一致していない。同様な結果は，石炭系活性炭 について報告されている ${ }^{19)}$ 。しかし，本報告ではXPS, FT-IRお よびTPDから得られた官能基量の傾向は比較的よく一致する 結果が得られた。したがって，この三つの手法を用いることで $\mathrm{ACs}-\mathrm{O}$ 表面の官能基の種類および含有量がある程度までは推定 できることが示唆された。

\section{7 表面官能基の生成機構}

Fig. 6にACs-orig. の電解酸化による表面官能基の生成過程の モデルを示す。Fig. 6 a)では印加電圧 $1.5 \mathrm{~V}$ までは，電解酸化に

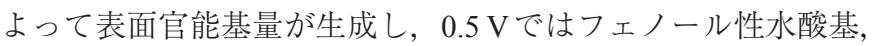
$0.5 \sim 1.5 \mathrm{~V}$ ではラクトン基が多く生成した。比較的に穏やかな 電解酸化条件ではACs-orig.のエッジ表面が酸化されてこれら しい酸化条件下では印加電圧の増加に伴いカルボキシル基が多 く生成したが，フェノール性水酸基の量は大きく変化しなかっ

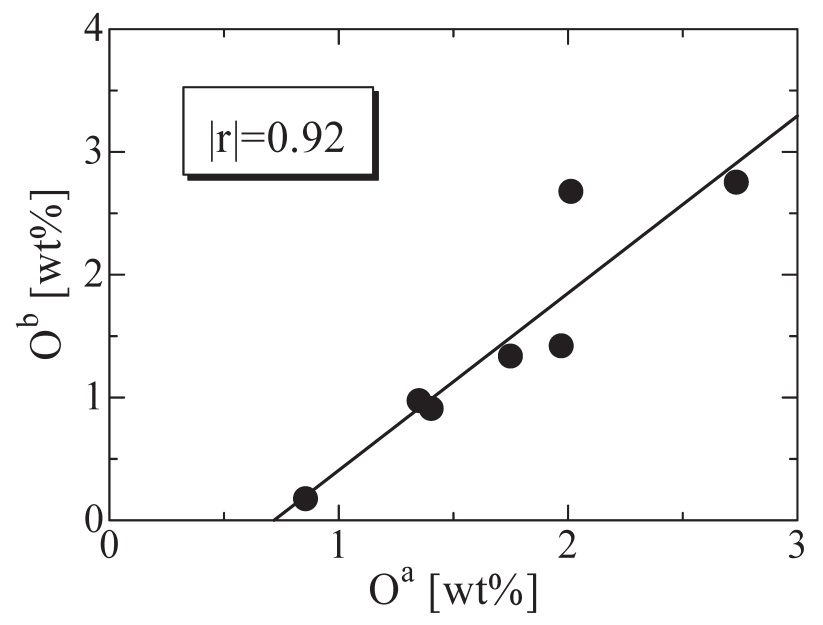

Fig. 5 Relationship between the oxygen content determined from the titration method and TPD. $\mathrm{O}^{\text {a }}$; Oxygen content calculated from the amount phenol, lactone and carboxyl by using the titration. $\mathrm{O}^{\mathrm{b}}$; Oxygen content calculated from the amount $\mathrm{CO}$ and $\mathrm{CO}_{2}$ by using TPD. の官能基が生成するものと考えられる。一方，1.5 V以上の厳 
た。これは，厳しい酸化条件下ではエッジ面の酸化およびエッ ジ面に生成している官能基の逐次酸化に加え，Fig. 6 b)に示す ような炭素網平面であるべーサル表面の酸化が起こっているも のと考えられる。この酸化過程ではカルボキシル基，ラクトン 基，フェノール性水酸基も同時に生成するが，フェノール性水 酸基やラクトン基はカルボキシル基への逐次酸化 ${ }^{5)}$ も平行して 進行するため, $1.5 \mathrm{~V}$ 以上ではフェノール性水酸基およびラク トン基の生成量に大きな変化が見られなかったと考えられる。 これは, Fig. 6 c)に示すような活性炭繊維布の電解酸化の反応 機構が提案されており ${ }^{5)}$, 本実験結果においても同様な傾向が 見られた。

\section{4. 結 言}

電解酸化処理により，ACs-orig. 表面に細孔構造に大きな変 化を与えず，表面官能基を生成することが可能であった。生成 した官能基は，穏やかな酸化条件下ではフェノール性水酸基お よびラクトン基, 強い酸化条件化ではカルボキシル基が多く生 成した。これらの官能基の定性および定量の結果は, 種々の評 価方法の測定結果と比較的一致する結果が得られた。

電解酸化処理法および各種評価法により, 印加電圧と生成す る表面官能基との関連を示した。この結果はまだよく理解され ていない部分もあるが，炭素材料の表面反応に関する理解が深 まることで，炭素表面の設計および応用に関しても寄与するも のと思われる。

\section{謝 辞}

本研究の一部は, 文部科学省私立大学戦略的研究基盤形成支 援事業（平成24 28 年), JSPS 科研費 26340081, 平成 25 年度大 阪府地域産業支援力強化事業補助金により補助を受けて行われ た。記して謝意を表する。

\section{文 献}

1) M. Inagaki, New carbons-control of structure and functions (2000), pp. 1-240, Elsevier Science, Amsterdam.

2) N. Oyama, A. P. Brown and F. C. Anson, J. Electroanal. Chem. 87 (1978) 435-441.

3) R. Nowak, F. A. Schultz, M. Umana, H. Abruña and R. W. Murray, $J$. Electroanal. Chem. 94 (1978) 219-225.

4) H. Oda, TANSO 2008 [No.235] 296-306 [in Japanese].

5) Z. R. Yue, W. Jiang, L. Wang, S. D. Gardner and C. U. Pittman Jr., Carbon 37 (1999) 1785-1796.

6) S. Toshinari, K. Kato, S. Yoshioka, K. Chikuba, K. Nakagawa and H. Oda, TANSO 2010 [No.242] 55-59 [in Japanese].

7) H. Hara, T. Kinumoto, T. Tsumura and M. Toyoda, TANSO 2012 [No.255] 245-253 [in Japanese].

8) H.-S. Choo, T. Kinumoto, S.-K. Jeong, Y. Iriyama, T. Abe and Z. Ogumi, J. Electrochem. Soc. 154 (2007) B1017-B1023.

9) H.-S. Choo, T. Kinumoto, M. Nose, K. Miyazaki, T. Abe and Z. Ogumi, J. Power Sources 185 (2008) 740-746.

10) M. Nose, T. Kinumoto, H.-S. Choo, K. Miyazaki, T. Abe and Z. Ogumi, Fuel Cells 9 (2009) 284-290.

11) H. P. Boehm and M. Voll, Carbon 8 (1970) 227-240.

12) D. Mowla, D. D. Do and K. Kaneko, Chem. Phys. Carbon 28 (2003) 229-262.

13) S. Reiche, R. Blume, X. C. Zhao, D. Su, E. Kunkes, M. Behrens and R. Schlögl, Carbon 77 (2014) 175-183.

14) P. E. Fanning and M. A. Vannice, Carbon 31 (1993) 721-730.

15) B. K. Pradhan and N. K. Sandle, Carbon 37 (1999) 1323-1332.

16) C. Ishizaki and I. Marti, Carbon 19 (1981) 409-412.

17) J. L. Figueiredo, M. F. R. Pereira, M. M. A. Freitas and J. J. M. Órfão, Carbon 37 (1999) 1379-1389.

18) H. F. Gorgulho, J. P. Mesquita, F. Gonçalves, M. F. R. Pereira and J. L. Figueiredo, Carbon 46 (2008) 1544-1555.

19）堤 和男，萩原茂示，新版活性炭一基礎と応用（真田雄三，鈴木 基之，藤本 薰編）(1992) pp. 11-12, 講談社 